\title{
Changing Spectrum of Squamous Cell Abnormalities Observed on Papanicolaou Smears in Mubarak Al-Kabeer Hospital, Kuwait, over a 13-Year Period
}

\author{
Kusum Kapila $^{a}$ Sara S. George $^{a}$ Azza Al-Shaheen $^{\mathrm{b}}$ M.S. Al-Ottibi ${ }^{\mathrm{b}}$ \\ Shahed K. Pathan ${ }^{b}$ Zafar A. Sheikh ${ }^{b}$ Bahiya E. Haji ${ }^{b}$ Mrinmay K. Mallik $^{b}$ \\ Dilip K. Das ${ }^{\text {a }}$ Issam M. Francis ${ }^{a}$ \\ ${ }^{a}$ Department of Pathology, Faculty of Medicine, Kuwait University, and ${ }^{b}$ Cytology Laboratory, \\ Mubarak Al-Kabeer Hospital, Kuwait
}

\section{Key Words}

Papanicolaou smear · Squamous lesions · Kuwait

\begin{abstract}
Objective: The aim of this study was to determine the incidence of squamous cell abnormalities in cervical cytology in Mubarak Al-Kabeer Hospital, Kuwait, and to document any change in the pattern of these lesions. Materials and Methods: Over a 13-year period (19922004), 86,434 cervical smears were studied in Mubarak Al-Kabeer Hospital, Kuwait. Conventional Pap smears were first examined by cytotechnicians and finally reported by cytopathologists. The smears were classified according to the modified Bethesda system. The age of presentation of squamous cell abnormalities in Kuwaiti women was analyzed. Results: Smears from 83,052 (96.09\%) patients were found satisfactory for reporting while the remaining $3.9 \%$ was unsatisfactory. Atypical squamous cells of undetermined significance (ASCUS) were seen in $1,790(2.2 \%)$ cases, atypical glandular cells of undetermined significance (AGUS) in 630 (0.8\%) cases, low grade squamous intraepithelial lesion including human papillomavirus changes (LSIL) in 824 (1.0\%) cases, high grade squamous intraepithelial lesion (HSIL) in
\end{abstract}

$189(0.2 \%)$ cases, and carcinoma in $79(0.1 \%)$ cases of which $44(0.05 \%)$ were squamous cell carcinoma. A comparison of average cases/annum during the study period revealed a significant increase in ASCUS from 1.13 to $2.83 \%(p<0.001)$ and AGUS from 0.33 to $1.08 \%$ ( $p<$ $0.001)$. However, the percentage of LSIL, HSIL and carcinoma detected in Pap smears remained the same. Conclusion: A significant linear trend ( $p<0.001$ ) was observed in satisfactory smears, ASCUS and AGUS over the years. However, no significant change was found in the detection of LSIL, HSIL and carcinoma. A reduction in the age of LSIL/HSIL and an increasing trend in the number of Kuwaiti women over the years was also observed which makes screening of young women essential in Kuwait.

Copyright @ 2006 S. Karger AG, Basel

\section{Introduction}

The available literature supports the importance of early detection of preneoplastic lesions in the cervix by cytological/colposcopical examination. The Pap smear plays an important role in screening programs in reducing both the incidence and mortality of invasive cancer [1].

\section{KARGER}

Fax +41613061234 E-Mail karger@karger.ch www.karger.com
(C) 2006 S. Karger AG, Basel

$1011-7571 / 06 / 0154-0253 \$ 23.50 / 0$

Accessible online at:

www.karger.com/mpp
Prof Kusum Kapila, MD, FAMS, FIAC, FRCPath

Department of Pathology, Faculty of Medicine

Kuwait University, PO Box 24923

13110 Safat (Kuwait)

Tel. +965 5319476 or 498 6247, Fax +965 533 8905, E-Mail kkapila@yahoo.com 
Table 1. Yearly analysis of Pap smear diagnoses from 1992 to 2004

\begin{tabular}{|c|c|c|c|c|c|c|c|c|c|c|c|c|c|c|}
\hline $\begin{array}{l}\text { Cytological } \\
\text { diagnosis }\end{array}$ & 1992 & 1993 & 1994 & 1995 & 1996 & 1997 & 1998 & 1999 & 2000 & 2001 & 2002 & 2003 & 2004 & Total \\
\hline \multicolumn{15}{|l|}{ Total } \\
\hline $\begin{array}{l}\text { Pap smears } \\
\text { Unsatisfactory }\end{array}$ & 4,625 & 5,343 & 5,475 & 6,004 & 5,720 & 6,337 & 7,302 & 7,865 & 8,146 & 7,452 & 7,288 & 7,265 & 7,612 & 86,434 \\
\hline smears & 93 & 63 & 704 & 759 & 886 & 126 & 96 & 156 & 120 & 103 & 101 & 72 & 103 & 3,382 \\
\hline Satisfactory & & & & & & & & & & & & & & \\
\hline smears & 4,532 & 5,280 & 4,771 & 5,245 & 4,834 & 6,211 & 7,206 & 7,709 & 8,026 & 7,349 & 7,187 & 7,193 & 7,509 & 83,052 \\
\hline ASCUS & $48(1.1)$ & $56(1.1)$ & $51(1.1)$ & $69(1.3)$ & $97(2.0)$ & $109(1.8)$ & $157(2.2)$ & $149(2.0)$ & $221(2.8)$ & $268(3.6)$ & $180(2.5)$ & $231(3.2)$ & $154(2.1)$ & $1,790(2.2)$ \\
\hline AGUS & $16(0.35)$ & $7(0.13)$ & $17(0.36)$ & $26(0.50)$ & $42(0.87)$ & $22(0.35)$ & $30(0.42)$ & $68(0.88)$ & $79(0.98)$ & $106(1.44)$ & $59(0.82)$ & $74(1.03)$ & $84(1.12)$ & $630(0.8)$ \\
\hline LSIL & $38(0.84)$ & $46(0.87)$ & $66(1.4)$ & $45(0.86)$ & $65(1.3)$ & $72(1.2)$ & $68(0.9)$ & $68(0.9)$ & $84(1.1)$ & 99 (1.4) & $57(0.8)$ & $62(0.9)$ & $54(0.7)$ & $824(1.0)$ \\
\hline HSIL & $4(0.09)$ & $31(0.59)$ & $9(0.19)$ & $11(0.21)$ & $9(0.19)$ & $15(0.24)$ & $13(0.18)$ & $11(0.14)$ & $21(0.26)$ & $12(0.16)$ & $18(0.25)$ & $16(0.22)$ & $19(0.25)$ & $189(0.2)$ \\
\hline Carcinoma & $7(0.15)$ & $4(0.08)$ & $5(0.10)$ & 0 & $3(0.06)$ & $1(0.02)$ & $8(0.11)$ & $6(0.08)$ & $13(0.16)$ & $8(0.11)$ & $9(0.13)$ & $7(0.10)$ & $8(0.11)$ & $79(0.1)$ \\
\hline
\end{tabular}

Figures in parentheses give the percentage with respect to the number of satisfactory smears.

Declining trends in cervical cancer in the USA are attributable to widespread use of cervical cytology screening programs which have counteracted increases anticipated from changes in risk factor prevalence [2]. The greatest barrier to effective cervical screening is patient ignorance [3].

Various investigators have described an increase in the incidence of cervical carcinoma and high grade cervical dysplasias among young women ( $<35$ years) in a screened population [4, 5] over the last 20 years or so. For counseling young women and for organizing a public health system it is important to know the incidence of cervical intraepithelial lesions in a country. A relatively low prevalence of abnormal smears and cervical cancer has been reported in the Muslim as compared with the Western population [6-12]. This is most likely related to sexual behavior under Islamic rules [10], the lack of awareness of cervical cancer risk factors among women, and the low awareness that routine gynecological examinations and Pap smears are essential $[11,13,14]$.

In view of the absence of screening programs in $\mathrm{Ku}-$ wait, there are only scant data available [15] with regard to Pap smear results. This study was carried out to determine the incidence and pattern of abnormal cytological entities seen in Pap smears in a hospital setting according to the modified Bethesda classification and to document any change in the spectrum of squamous cell abnormalities seen over the years.

\section{Material and Methods}

This retrospective study was designed to review the previous reports of 86,434 Pap smears performed in the cytology laboratory of Mubarak Al-Kabeer Hospital in Kuwait from January 1992 to
December 2004. Mubarak Al-Kabeer Hospital is a tertiary care hospital which provides cytological diagnostic services to 15 hospitals, 17 clinics and practitioners both in the Hawally and nonHawally areas. Specimen adequacy was assessed according to the presence of endocervical cells. The cytological diagnoses were changed where required to the modified Bethesda classification [16] adopted by the laboratory in 2002 . The categories used were normal, atypical squamous cells of undetermined significance (ASCUS), atypical glandular cells of undetermined significance (AGUS), low grade squamous intraepithelial lesion (LSIL) including changes induced by human papillomavirus (HPV), high grade squamous intraepithelial lesion (HSIL) and carcinoma.

For a 5-year period (2000-2004) the age and nationality of the women with epithelial cell abnormalities was retrieved from the files. Analysis was only conducted on Kuwaitis as non-Kuwaitis were not classified according to nationality where the prevalence from Arabia, Asia, Africa, Europe or America varied widely. The $\chi^{2}$ test was used to determine if there was any trend in the incident proportion of cases during the period of study (1992-2004).

\section{Results}

The spectrum of Pap smear diagnoses for each year is depicted in table 1 . Of the 86,434 Pap smears, 83,052 (96.09\%) were found satisfactory for analysis, and of these, $79,540(95.7 \%)$ were normal while 3,512 (4.3\%) had epithelial cell abnormalities (fig. 1a). These 3,512 smears fell into the following categories: ASCUS, 1,790 (2.2\%); AGUS, 630 (0.8\%); LSIL, 824 (1.0\%); HSIL, 189 $(0.2 \%)$, and carcinoma, $79(0.1 \%)$. Of the 3,512 smears, 2,847 had squamous cell abnormality (fig. 1b).

Of the 79 smears with malignant cells, 35 were glandular in origin while 44 were of the squamous cell type, which corresponds to a $0.05 \%$ incidence of squamous cell carcinoma in Kuwait. The women ranged in age from 28 to 80 with a mean of 48 years. 


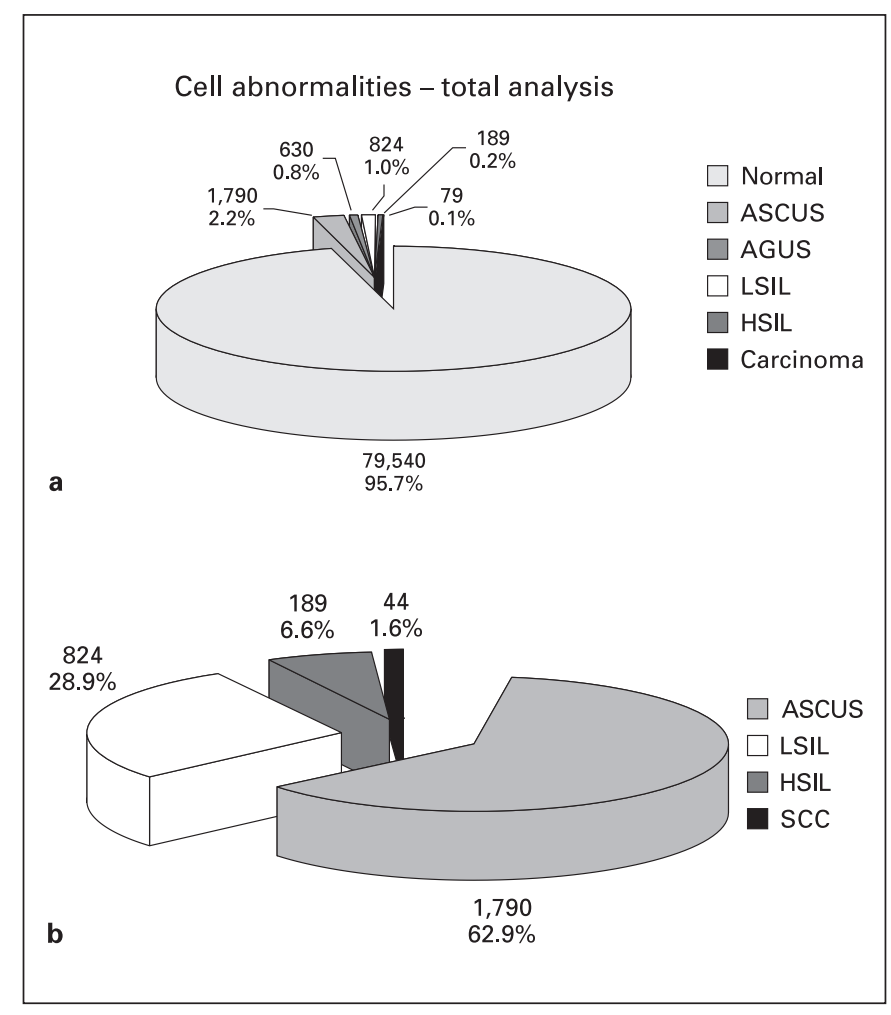

Fig. 1. a Diagnoses of 83,052 satisfactory Pap smears. b Distribution of squamous cell abnormalities in the Pap smears (1992-2004). SCC $=$ Squamous cell carcinoma.
When the incidence of ASCUS and AGUS among submitted smears was plotted against year of diagnosis (fig. 2), ASCUS increased from $1.06 \%$ in 1993 to $3.2 \%$ in 2003 and decreased slightly to $2.05 \%$ in 2004 while a minimal increase was observed in AGUS from $0.35 \%$ in 1993 to $1.12 \%$ in 2004. A significant linear trend $(\mathrm{p}<$ 0.001 ) was documented for ASCUS during the three periods 1992-1995, 1996-1999 and 2000-2004 (table 2).

The incidence rates of LSIL and HSIL when plotted against diagnosis year changed slightly from 0.96 to $1.05 \%$ for LSIL and from 0.18 to $0.28 \%$ for HSIL over the 3 study periods (table 2 ).

The age group of the Kuwaiti women was correlated with the incidence of premalignant lesions for 5 years only (2000-2004). The highest incidence of LSIL was in women in the age group 25-34 years with a significant $(p<0.001)$ number of women in the age group 15-24 years (fig. 3). The youngest reported case of LSIL was 17 years old. The peak age of HSIL was observed in women in the age group 25-34 years. There appeared to be an increase with 117 of the 221 cases $(p<0.001)$ of LSIL being in younger women (fig. 4). Six cases were less than 24 years of age and the youngest reported case of HSIL was 22 years old.

When preneoplastic lesions were analyzed among Kuwaiti and non-Kuwaiti women, an increasing trend of

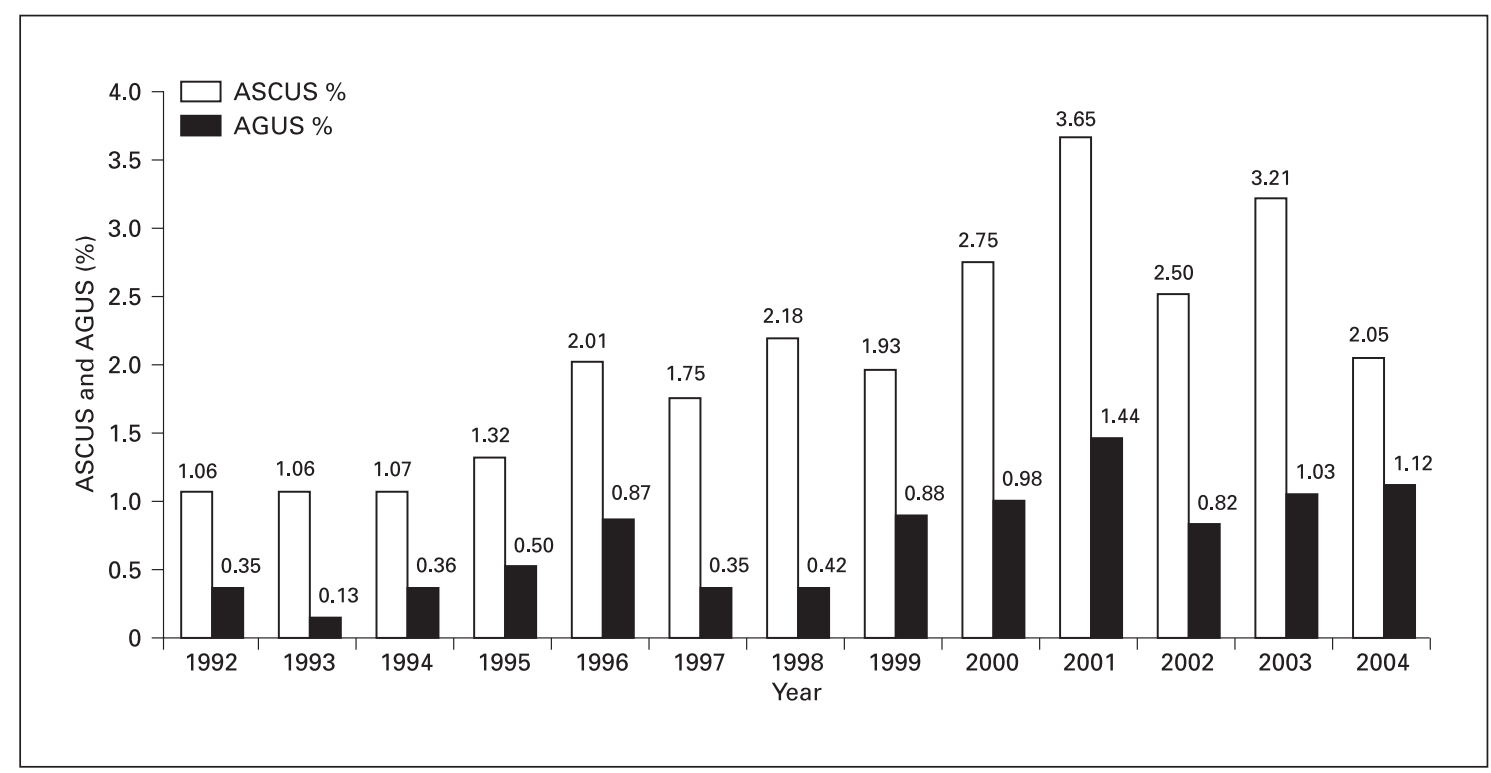

Fig. 2. Incidence of ASCUS and AGUS by year of diagnosis. 


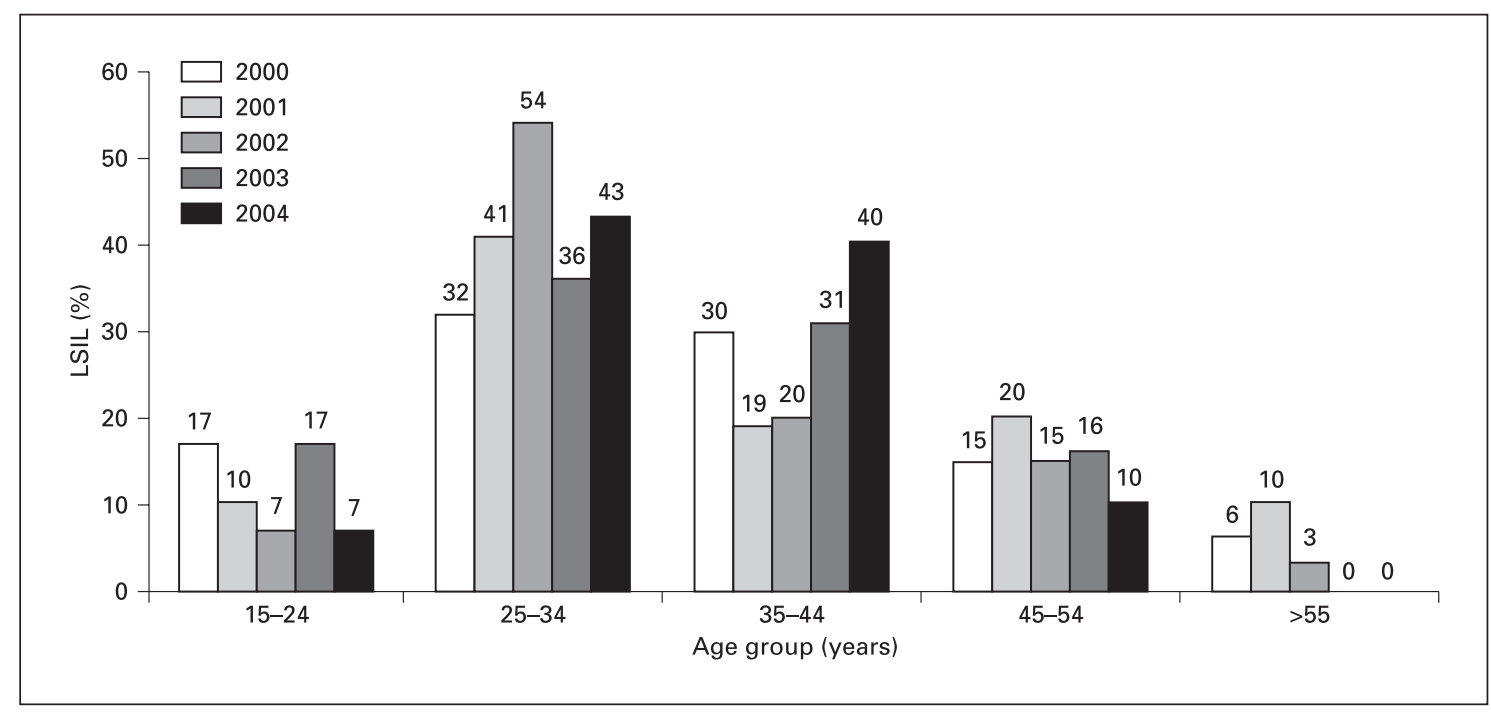

Fig. 3. Age distribution of Kuwaiti women with LSIL from 2000 to 2004.

Table 2. Average smears /lesions per annum by cytological diagnosis during 1992-2004 at Mubarak Al-Kabeer Hospital, Kuwait

\begin{tabular}{|c|c|c|c|c|c|c|}
\hline \multirow[t]{2}{*}{ Cytological diagnosis } & \multicolumn{3}{|c|}{ Average cases/annum } & \multicolumn{3}{|c|}{ Change, $\%$} \\
\hline & $1992-95(1)$ & 1996-99 (2) & 2000-04 (3) & 2 vs. 1 & 3 vs. 2 & 3 vs. 1 \\
\hline Total Pap smears, $\mathrm{n}$ & 5,362 & 6,806 & 7,553 & 26.9 & 11.0 & 40.9 \\
\hline Satisfactory smears $* * *$ & 4,957 & 6,490 & 7,453 & 30.9 & 14.8 & 50.3 \\
\hline ASCUS*** & $56(1.13)$ & $128(1.97)$ & $211(2.83)$ & 128.6 & 64.7 & 276.4 \\
\hline AGUS & $17(0.33)$ & $41(0.62)$ & $81(1.08)$ & $145.5^{*}$ & $99.4^{* *}$ & $389.4^{* * *}$ \\
\hline LSIL & $49(0.98)$ & $68(1.05)$ & $71(0.96)$ & 40.0 & 4.3 & 46.1 \\
\hline HSIL & $14(0.28)$ & $12(0.18)$ & $17(0.23)$ & -12.7 & 43.3 & 25.1 \\
\hline Carcinoma & $4(0.08)$ & $5(0.07)$ & $9(0.12)$ & 25.0 & 80.0 & 125.0 \\
\hline $\begin{array}{l}\text { Increase in satisfactory smears } \\
\text { with respect to total smears, } \%\end{array}$ & 92.15 & 95.4 & 98.7 & & & \\
\hline
\end{tabular}

Figures in parentheses give the percentage with respect to the number of satisfactory smears; ${ }^{*} \mathrm{p}<0.05$ $* * \mathrm{p}<0.01, * * * \mathrm{p}<0.001$.

both LSIL and HSIL was observed in Kuwaiti women from approximately $66 \%$ in 2000 to $79 \%$ in 2003 , and $67 \%$ in 2000 to $81 \%$ in 2002 , respectively. However, in 2004, LSIL decreased to $58 \%$ while HSIL decreased in 2003 and 2004. In the non-Kuwaiti population, LSIL and HSIL were variable ranging from 21 to $42 \%$ for LSIL and 19 to $46 \%$ for HSIL.

\section{Discussion}

Cancer of the uterine cervix is the second most common cancer in women worldwide after breast cancer. About 470,000 new cases are diagnosed each year, predominantly among the economically disadvantaged in both developing and industrialized nations [17]. Invasive cervical cancer is preceded by a spectrum of heterogeneous epithelial lesions over a long period. Identification of relevant risk factors and prompt management of the 


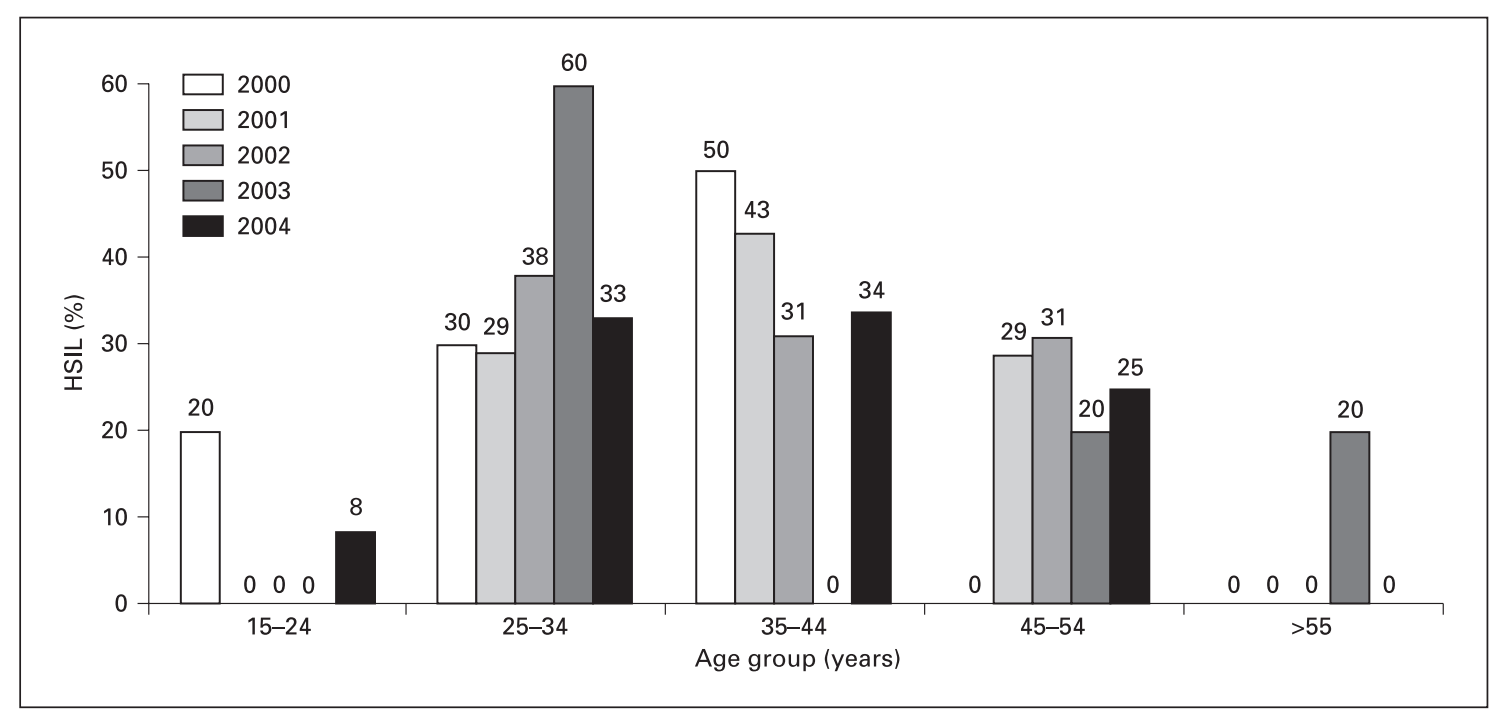

Fig. 4. Age distribution of Kuwaiti women with HSIL from 2000 to 2004.

precancerous lesions are important in the prevention of invasive cancer of the uterine cervix. To address the need for screening in Kuwait it is important to document the magnitude of cervical preneoplastic lesions and cancer prevalent in the country.

Premalignant lesions termed cervical intraepithelial neoplasia (CIN) or squamous intraepithelial lesions are classified into several grades - CIN I or LSIL and CIN 2/CIN 3 or HSIL. In principle these premalignant lesions are reversible, although the more severe the lesion, the less the chance of spontaneous regression [1]. Cervical cancer is considered a preventable disease because the premalignant stages can be detected by exfoliative cytology. Other alternative methods that have been proposed include unaided direct visual inspection (downstaging) and application of acetic acid along with colposcopy. Currently, cervical screening is based on cytology alone [18]. The risk of developing cervical cancer is associated with early age of first intercourse, multiple sexual partners, smoking, and infection with HPV [19].Because infection with high-risk HPV types (hr HPV) has recently been implicated as a necessary cause of cervical cancer [20], screening has become more efficient when it is based on a combination of the Pap smear and hr HPV testing [1, $21,22]$.

In this study, a Pap smear abnormality of $4.3 \%$ is comparable to that reported in other Middle East countries which ranges from $0.95 \%$ in Jewish Israeli women [9] to $1.66 \%$ in the Western region of Saudi Arabia [10], and as high as $7.9 \%$ in Southwestern Saudi Arabia [11]. The majority of abnormal smears were ASCUS (fig. 1b) with a steady increase in the incidence from 1.06 in 1992 to $3.2 \%$ in 2003 (fig. 2). This incidence rate is similar to those reported by Elhakeem et al. (2.8\%) for Southwestern Saudi Arabia [11], to 3.5\% (range, 2.7-4.9\%) in the Kaiser study from 4 institutions [23], and to $4.5 \%$ by the College of American Pathologists using conventional cytological smears [24]. Few laboratories have reported an increase in an ASC (atypical squamous cell) rate as high as $10.32 \%$ after implementation of the 2001 Bethesda system [25]. It is important to document these cells for it has been shown that women with an ASCUS Pap smear have a $7 \%$ greater risk of harboring CIN 2/CIN 3 than those with a normal Pap smear [26]. However, it should be pointed out that the 2001 Bethesda system further categorizes atypical squamous cells into 'ASC-H' (atypical squamous cells, cannot rule out a HSIL). In this study we were unable to provide this data as the ASCUS slides were not reviewed for further subclassification.

The incidence of LSIL and HSIL did not vary over the 13 -year period of study and averaged 1.0 and $0.2 \%$, respectively, comparable to cases in Southwestern Saudi Arabia (1.3\% LSIL and 0.66\% HSIL [11]), in Jewish Israeli women (0.69\% LSIL and HSIL 0.29\% [9]), and the Western world (1.6\% LSIL and 0.5\% HSIL [22]). However, there are other studies where the incidence rates are higher such as in South Africa (2.4\% LSIL, 1.8\% HSIL) [27], and both before and after implementation of the 
2001 Bethesda system (3.56\% to 5.1\% for LSIL and 5.36\% to $6.5 \%$ for HSIL) [25].

In this study, the age of peak incidence (API) for LSIL (25-34 years) (fig. 3) was different to that observed in Southwestern Saudi Arabia (50-59 years) [9] and in Jewish Israeli women (20-24 years) [11]. A probable explanation is that LSIL which incorporates HPV-related changes was seen increasingly in Pap smears of women less than 20 years old and because their number appears to be on the rise. The API for HSIL in our study was 35-44 years (fig. 4) as compared to 40-49 years in the study from Southwestern Saudi Arabia [9] and 30-39 years in Jewish Israeli women [11]. The proportion of Kuwaiti women with LSIL in the Pap smear appeared to rise from $66 \%$ in 2000 to $79 \%$ in 2003. HSIL also showed an increasing trend in Kuwaiti women. In non-Kuwaiti women there was no consistent increase in either LSIL or HSIL.

Cancer of the uterine cervix is the fifth most common cancer in Kuwaiti females (4.6\%) with an age standardized incidence rate of $6.8 / 100,000$ [28]. It is commonly reported in Kuwaiti women $\geq 55$ years [28]. In the current study, squamous cell carcinoma was seen in $0.05 \%$ of the cases in the age range between 28 to 80 years which had a mean of 48 years. The API for cervical carcinoma in Saudi Arabia was 50-59 years [11]. The relatively lower prevalence of cervical lesions and cervical cancer may be related to sexual behavior and the practice of circumcision $[9,11]$.
Squamous cell abnormalities and invasive squamous cell carcinoma are less frequently encountered in Kuwaiti [28] and Saudi Arabian [9] women as compared to women in the Western world [28]. A probable explanation is that fewer women are screened due to their social/cultural background, and their lack of awareness of the importance of an annual Pap smear [13, 14]. It must also be kept in mind that this is a hospital-based collection of data and there could be an inherent bias. A larger community-based study may establish the exact prevalence of malignant and preneoplastic lesions of the uterine cervix in Kuwait.

\section{Conclusion}

The data show that there was an increase in incidence of ASCUS and AGUS but no significant change in LSIL and HSIL over the years. However, LSIL seems to be occurring at an earlier age, thereby making it essential to institute a screening program requiring the high participation of young women.

\section{Acknowledgements}

The authors would like to thank Dr. Prem Sharma, Technical Adviser, Health Sciences Computer Center, Kuwait University, for help in the statistical analysis of the data and Mr. James Luke for preparation of the manuscript.

\section{References}

1 Brink AATP, Zielinski GD, Steenbergen RDM, Snijders PJF, Meijer CJLM: Clinical relevance of human papillomavirus testing in cytopathology. Cytopathology 2005;16:7-12.

-2 Devesa SS, Young JL Jr, Brinton LA, Franmeni JF Jr: Recent trends in cervix uteri cancer. Cancer 1989;64:2184-2190.

3 Lee SS, Wong LC: Cervical smear screening: questionnaire study of histories and attitudes of patients with squamous cervical carcinoma. Hong Kong Med J 1999;5:229-232.

-4 Blohmer J, Schmalisch G, Klette I, Grineisen V, Kohls A, Guski H, Lichtenegger W: Increased incidence of cervical intraepithelial neoplasia in young women in Mitte District, Berlin, Germany. Acta Cytol 1999;43:195200.

5 DiSaia PJ, Creaseman WT (eds): Clinical Gynecologic Oncology. St Louis, Mosby, 1997, p 57.

6 Abdu Dahab A, Al-Salih A: An overview of cervical abnormalities at the maternity and children hospital (Jeddah) over one year. Saudi J Obstet Gynecol 2002;2:143-148.
7 Abduljabbar HS: Abnormal cervical cytology, a preliminary report from western region of Saudi Arabia. Saudi Med J 1990;11:372-373.

-8 Altaf F: Pattern of cervical smear cytology in the Western region of Saudi Arabia. Ann Saudi Med 2001;21:94-96.

-9 Sadan O, Schejter E, Ginath S, Bachar R, Boaz M, Menczer J, Glezerman M: Premalignant lesions of the uterine cervix in a large cohort of Israeli Jewish women. Arch Gynecol Obstet 2004;269:188-191.

10 Jamal AA, Al-Maghrabi JA: Profile of Pap smear cytology in the Western region of Saudi Arabia. Saudi Med J 2003;24:1225-1229.

$>11$ Elhakeem HA, Al-Ghamdi AS, Al-Maghrabi JA: Cytopathological pattern of cervical Pap smear according to the Bethesda system in Southwestern Saudi Arabia. Saudi Med J 2005; 26:588-592.

12 Wasti S, Ahmed W, Jafri A, Khan B, Sohail R, Hassan S: Analysis of cervical smears in a Muslim population. Ann Saudi Med 2004;24:189192.
13 Bener A, Denic S, Alwash R: Screening for cervical cancer among Arab women (brief communication). Int J Gynaecol Obstet 2001;74: 305-307.

14 Maaita M, Barakat M: Jordanian women's attitudes towards cervical screening and cervical cancer. J Obstet Gynaecol 2002;22:421-422.

15 Luthra UK, Chishti M, Dey P, Jolly SV, Abdulla M, Das DK, Sugathan TN, Ajrawi MT, Goerge J, George SS, Aziz AA, Al-Juwaiser A, Karim FA, Mallik MK, Sheikh ZA, Khan S: Performance of monolayered cervical smears in a Gynecology outpatient setting in Kuwait. Acta Cytol 2002;46:303-310.

16 Solomon D, Davey D, Kurman R, Moriarty A, O'Connor D, Prey M, Raab S, Sherman M, Wilbur D, Wright T Jr, Young N: The 2001 Bethesda system terminology for reporting results of cervical cytology. JAMA, 2002;287: 2114-2119

17 Parkin DM, Bray F, Feslay J, Pisani P: Estimating the world cancer burden: Globocan 2000. Int J Cancer 2001;94:153-156. 
18 Renshaw AA, Davey DD, Birdsong GG, Walsh MM, Styer PE, Mody DR, Colgan TJ: Precision in gynecologic cytologic interpretation: a study from the College of American Pathologists Interlaboratory Comparison Program in Cervicovaginal Cytology. Arch Pathol Lab Med 2003;127:1413-1420.

19 American Cancer Society: Cancer Facts and Figures 1999. Atlanta, American Cancer Society, 1999.

20 Walboomers JM, Jacobs MV, Manos WM, Bosch FX, Kummer JA, Shah KV, Snijders PJ, Peto J, Meijer CJ, Munoz N: Human papillomavirus is a necessary cause of invasive cervical cancer worldwide. J Pathol 1999;189:1219.

-21 Lorincz AT, Richart RM: Human papillomavirus DNA testing as an adjunct to cytology in cervical screening programs. Arch Pathol Lab Med 2003;127:959-968.
22 Davey DD, Woodhouse S, Styer P, Stastny J, Mody D: Atypical epithelial cells and specimen adequacy: current laboratory practices of participants in the College of American Pathologists Interlaboratory Comparison Program in Cervicovaginal Cytology. Arch Pathol Lab Med 2000;124:203-211.

23 Manos MM, Kinney WK, Hurley LB, Sherman ME, Shieh-Ngai J, Kurman RJ, Ransley JE, Fetterman BJ, Hartinger JS, Mcintosh KM, Pawlick GF, Hiatt RA: Identifying women with cervical neoplasia: using human papillomavirus DNA testing for equivocal Papanicolaou results. JAMA 1999;281:1605-1610.

24 Kendall BS, Bush AC, Olsen CH, Zahn CM: Reflex high-risk human papillomavirus testing for women with atypical squamous cells of undetermined significance in cytologic smears: effects since implementation in a large clinical practice. Am J Clin Pathol 2005;123:524528.
25 Chhieng DC, Roberson J, Gidley J, Eltoum I: Bethesda 2001. Impact on the reporting of gynecologic cytology. Acta Cytol 2004;48:355362 .

26 Nygard JF, Sauer T, Skjeldestad FE, Skare GB, Thoresen SO: CIN 2/3 and cervical cancer after an ASCUS Pap smear. A 7-year, prospective study of the Norwegian population - based, coordinated screening program. Acta Cytol 2003; 47:991-1000.

27 Fonn S, Bloch B, Mabina M, Carpenter S, Cronje $\mathrm{H}$, Maise $\mathrm{C}$, et al: Prevalence of precancerous lesions and cervical cancer in South Africa - a multicentre study. S Afr Med J 2002; 98:148-156.

28 Kuwait Cancer Registry: Annual Report 2001 Kuwait, Ministry of Health, State of Kuwait, 2001, pp 30, 85. 